\title{
Methane efflux from an American bison herd
}

\author{
Paul C. Stoy ${ }^{1,2,3 *}$, Adam A. Cook ${ }^{3}$, John E. Dore ${ }^{3,4}$, William Kleindl ${ }^{3}$, E. N. Jack Brookshire ${ }^{3}$, Tobias
} Gerken $^{5}$

${ }^{1}$ Department of Biological Systems Engineering, University of Wisconsin, Madison, WI, USA

$5 \quad{ }^{2}$ Department of Atmospheric and Oceanic Sciences, University of Wisconsin, Madison, WI, USA

${ }^{3}$ Department of Land Resources and Environmental Sciences, Montana State University, Bozeman, MT, USA

${ }^{4}$ Montana Institute on Ecosystems, Montana State University, Bozeman, MT, USA

${ }^{5}$ Department of Meteorology and Atmospheric Science, The Pennsylvania State University, University Park, PA, USA

Correspondence to: Paul C. Stoy (pcstoy@wisc.edu)

Abstract. American bison (Bison bison L.) have recovered from the brink of extinction over the past century. Bison reintroduction creates multiple environmental benefits, but their impacts on greenhouse gas emissions are poorly understood. Bison are thought to have produced some $2 \mathrm{Tg}_{\text {year }}{ }^{-1}$ of the estimated 9-15 $\mathrm{Tg}$ year $^{-1}$ of pre-industrial enteric methane emissions, but few contemporary measurements have been made due to their mobile grazing habits and safety issues associated with direct measurements. Here, we measure methane and carbon dioxide fluxes from a bison herd on an enclosed pasture during daytime periods in winter using eddy covariance. Methane emissions from the study area were negligible in the absence of bison (mean \pm standard deviation $=0.0024 \pm 0.042 \mu \mathrm{mol} \mathrm{m}^{-2} \mathrm{~s}^{-1}$ ) and were significantly greater than zero, $0.048 \pm 0.082$ $\mu \mathrm{mol} \mathrm{m} \mathrm{m}^{-2} \mathrm{~s}^{-1}$ with a positively skewed distribution, when bison were present. We coupled an eddy covariance flux footprint analysis with bison location estimates from automated camera images to calculate a mean (median) methane flux of $38 \mu \mathrm{mol}$ $\mathrm{s}^{-1}\left(22 \mu \mathrm{mol} \mathrm{s}^{-1}\right)$ per animal, or $52 \pm 14 \mathrm{~g} \mathrm{CH}_{4}$ day $^{-1}\left(31 \mathrm{~g} \mathrm{CH}_{4}\right.$ day $\left.^{-1}\right)$, less than half of measured emission rates for range cattle. Emission estimates are subject to spatial uncertainty in bison location measurements and the flux footprint, but from our measurements there is no evidence that bison methane emissions exceed those from cattle. We caution however that our measurements were made during winter and that evening measurements of bison distributions were not possible using our approach. Annual measurements are ultimately necessary to determine the greenhouse gas burden of bison grazing systems.

25 Eddy covariance is a promising technique for measuring ruminant methane emissions in conventional and alternate grazing systems and can be used to compare them going forward.

\section{Introduction}

The American bison (Bison bison L.) was hunted to near extinction during European expansion across North America (Flores 1991, Isenberg 2000, Smits 1995). Fewer than 100 reproductive individuals existed on private ranches in the United States

30 during the late $19^{\text {th }}$ Century from an original population of $30-60$ million (Hedrick, 2009). The current bison population of about 500,000 is due to the collective efforts of sovereign Indian tribes, government agencies, and private landowners (Gates 
https://doi.org/10.5194/bg-2020-38

Preprint. Discussion started: 25 February 2020

(c) Author(s) 2020. CC BY 4.0 License.

\section{(c) (i)}

et al., 2010; Sanderson et al., 2008; Zontek, 2007). Bison numbers are likely to further increase, increasing the incentive for researchers and land managers to understand the environmental impacts of their expansion.

The ecological role of bison has become better understood as populations have recovered (Allred et al., 2001; Hanson 1994;

35 Knapp et al., 1999). Bison feed preferentially on grasses (Plumb and Dodd, 1993; Steuter and Hidinger, 1999) and enhance forb diversity as a result (Collins, 1998; Hartnett et al., 1996, Towne et al., 2005). They tend to graze in preferred meadows during winter and search broadly for the most energy-dense forages in summer (Fortin et al., 2003), often in areas which have recently burned (Allred et al., 1991; Coppedge and Shaw, 1998; Vinton et al., 1993). Bison also do not migrate to follow the 'green wave' of fresh vegetation during spring green-up like other ungulates; rather, their vigorous grazing tends to stimulate

40 plant growth and create fresh, nutrient-rich foliage (Geremia et al., 2019). Combined, these observations suggest that bison select for forage quality rather than quantity which likely impacts their efflux of methane - which all ruminants emit, largely through eructation - because ruminant methane emission is related to the cellulose and hemicellulose intake of their diet (Moe and Tyrrell, 1979). It remains unclear how much methane results from the cellulose-rich grass-dominated diet of bison given their preference for fresh foliage and if management for bison may increase or diminish the greenhouse gas burden of ruminantbased agriculture.

Methane is a highly potent greenhouse gas and has about 3.7 times the global warming potential of carbon dioxide on a permole basis (Lashof and Ahuja, 1990). Atmospheric methane concentrations have been rising at an accelerated rate since 2016 for reasons that remain unclear (Nisbet et al., 2019) and there is an urgent need to improve our understanding of its surfaceatmosphere flux. Between 30 and 40 percent of anthropogenic methane emissions are due to enteric fermentation in livestock

50 (Kirschke et al., 2013) and the greenhouse gas burden of cattle alone is some $5 \mathrm{Pg}$ of carbon dioxide equivalent per year (Gerber et al., 2013; FAO, 2017). Recent studies have revised methane emission estimates from livestock upward by over 10\% (Beauchemin et al., 2008; Thornton and Herrero, 2010; Wolf et al., 2017), further emphasizing their critical role in global greenhouse gas budgets. Reducing unnecessary greenhouse gas emissions is a global imperative for Earth system management and reducing enteric methane sources is seen as a promising approach to do so (Boadi et al., 2002; DeRamus et al., 2003;

55 Herrero, et al., 2016; Hristov et al., 2013; Johnson and Johnson, 1995; Moss et al., 2000).

Bison in North America are thought to have been responsible for some $2.2 \mathrm{Tg}_{\text {year }}{ }^{-1}$ (Kelliher and Clark, 2010; Smith et al., 2016) of the 9-15 Tg year $^{-1}$ of pre-industrial enteric methane emissions (Thompson et al., 1993; Chappellaz et al., 1993; Subak, 1994). Enteric $\mathrm{CH}_{4}$ emissions from wild ruminants in the United States in the pre-settlement period comprised some $86 \%$ of current $\mathrm{CH}_{4}$ emissions from domesticated ruminants assuming an historic bison population size of 50 million (Hristov, 2012).

60 The important role of bison to past methane fluxes suggests that current their role in the global methane budget must be understood as their populations increase. Previous approaches used inventory approaches or scaling equations that were not derived using methane efflux measurements from bison; the only direct bison methane flux observations that we are aware of measured $30 \mathrm{~L}$ per kg dry food intake in one-year-old penned female bison fed alfalfa pellets (Galbraith et al., 1998), more than elk (Cervus elaphus) and white-tailed deer (Odocoileus virginianus) on a dry matter intake basis. Cattle methane 
https://doi.org/10.5194/bg-2020-38

Preprint. Discussion started: 25 February 2020

(c) Author(s) 2020. CC BY 4.0 License.

(c) (i)

65 emissions tend to be greater when fed alfalfa than grass (Chaves et al., 2006) such that existing published values may not represent an accurate estimate of the methane efflux from bison in a natural field setting, which has not been measured to date. Here, we measure methane flux from a bison herd on winter pasture using the eddy covariance technique (Dengel et al., 2011; Felber et al., 2015; Prajapati and Santos, 2018; Sun et al., 2015). We use a flux footprint analysis combined with bison locations determined using automated cameras to estimate methane flux on a per-animal basis and discuss observations in the context

70 of eddy covariance methane flux measurements from other ruminants and methane efflux from ruminant grazing systems.

\section{Methods}

\subsection{Study site}

The study site is a 5.5-hectare pasture that is intermittently grazed in winter by a herd of 40 bison on the Flying D Ranch near Gallatin Gateway, Montana, USA (45.557, -111.229). The pasture sits on a floodplain immediately west of the Gallatin River

75 (Figure 1). Daily high temperatures average $1.6^{\circ} \mathrm{C}$ and daily low temperatures average $-11.5^{\circ} \mathrm{C}$ at Bozeman-Yellowstone International Airport, located $24 \mathrm{~km}$ north-northeast of the site, during the November - February measurement period. Bozeman-Yellowstone airport records an average of $18.2 \mathrm{~mm}$ of precipitation per month during November - February, almost entirely as snowfall. Bison entered the pasture on November 17, 2017 and left on February 3, 2018. They consumed a mixture of perennial grasses grown in situ that was supplemented by perennial grass hay grown in nearby fields.

\section{$80 \quad 2.2$ Instrumentation}

A $3 \mathrm{~m}$ tower was installed near the center of the study pasture during November 2017 (Figure 1) and surrounded by electric fencing to avoid bison damage. Four game cameras (TimelapseCam, Wingscapes, EBSCO Industries, Inc., Birmingham, AL, USA) were mounted to the tower and pointed in cardinal directions. Two additional game cameras were mounted near the pasture edge facing the tower. Cameras captured images every five minutes and an example of an individual image from the

85 south-facing camera located on the northern edge of the study pasture is shown in Figure 2. Bison locations at the half-hourly time interval of the eddy covariance measurements were estimated by manually attributing bison locations to squares in a $20 \mathrm{~m}$ grid overlaid on the pasture area (Figure 1). The $20 \mathrm{~m}$ grid size represents the grid that we felt that we were able to attribute bison locations to given available observations. We test the sensitivity of these bison location estimates as described in the Spatial Uncertainty section below.

90 Incident and outgoing shortwave and longwave radiation and thereby the net radiation were measured using a NR01 net radiometer (Hukseflux, Delft, The Netherlands) mounted 1.5 meters above ground level. A SR50 sonic distance sensor (Campbell Scientific Inc., Logan, UT, USA) was installed at $1.3 \mathrm{~m}$ to gauge snow depth, and air temperature and relative humidity were measured at 2.25 meters using a HMP45C probe (Vaisala, Helsinki Finland). Average soil moisture and 
https://doi.org/10.5194/bg-2020-38

Preprint. Discussion started: 25 February 2020

(c) Author(s) 2020. CC BY 4.0 License.

\section{(c) (i)}

temperature between 0-30 $\mathrm{cm}$ were collected using CS650 probes (Campbell Scientific). Meteorological variables were measured once per minute, and half-hourly averages were stored using a CR3000 datalogger (Campbell Scientific).

Three-dimensional wind velocity was measured using a CSAT-3 sonic anemometer (Campbell Scientific) at $2.0 \mathrm{~m}$ above the ground surface. Carbon dioxide mixing ratios were measured at $10 \mathrm{~Hz}$ using a LI-7200 closed-path infrared gas analyzer (LICOR Biosciences, Inc.) with inlet placed at the same height as the center of the sonic anemometer. Methane mixing ratios were measured at $10 \mathrm{~Hz}$ using a LI-7700 open-path infrared gas analyzer (LI-COR Biosciences, Inc., Lincoln, NE, USA) with the center of the instrument likewise located at $2.0 \mathrm{~m}$. Open and closed path methane sensors for eddy covariance have been found to perform similarly in field settings (Detto et al., 2011; Deventer et al., 2019). We use the atmospheric convention in which flux from biosphere to atmosphere is positive. Measurements were made during daytime hours from 0700 to 1700 local time to avoid depleting the battery bank and to ensure sufficient light to estimate bison location using game cameras. Flux measurements began on November 14, 2017 and ended on February 14, 2018.

105 Wild and managed bison are dangerous and will charge humans. Therefore, their presence complicated data retrieval and game camera upkeep; some high-frequency flux measurements were overwritten and cameras shut down during exceptionally cold periods, resulting in missing measurements. Simultaneous flux and photographic data were obtained for the January 7, 2018 to February 13, 2018 period excluding January 10, 2018 when instruments were obstructed by snowfall. Flux data without accompanying game camera footage were obtained for the periods from November 14 through 29, 2017 and December 31,

110 2017, through January 6, 2018.

\subsection{Flux calculation}

Methane and carbon dioxide fluxes were calculated using EddyPro (LI-COR Biosciences, Lincoln, NE, USA). Standard double rotation, block averaging, and covariance maximization with default processing options were applied. Spike removal was performed as described by Vickers and Mahrt (1997) and spikes were defined as more than 3.5 standard deviations from the

115 mean mixing ratio for carbon dioxide and more than 8 standard deviations from the mean mixing ratio for methane given the expectation of intermittent methane spikes from the bison herd. The default drop-out, absolute limit, and discontinuity tests were applied using the default settings following recommendations by Dumortier et al. (2019), and the Moncrieff et al. (1997) and Moncrieff et al. (2004) low and high-pass filters were applied. The Webb-Pearman-Leuning correction (Webb et al., 1980) was applied to calculate methane efflux using the open-path LI-7700 sensor. Flux measurements for which the quality control

120 flag was greater than 1 following Mauder and Foken (2004) (see also Foken et al., 2004) were discarded. Estimates of storage flux in the $2 \mathrm{~m}$ airspace below the infrared gas analyzers were assumed to be minor and excluded from the flux calculation. We tested the sensitivity of flux measurements to the friction velocity $\left(u^{*}\right)$ to see if measurements made under conditions of insufficient turbulence should be excluded from the analysis despite the daytime-only flux measurement approach. 
https://doi.org/10.5194/bg-2020-38

Preprint. Discussion started: 25 February 2020

(c) Author(s) 2020. CC BY 4.0 License.

(c) (i)

Discussions

\subsection{Footprint calculation}

125 The eddy covariance flux footprint was calculated using the approach of Hsieh et al. (2000) extended to two dimensions following Detto and Katul (2006). Analytical footprint models have been found to give minimally-biased estimates of pointsource fluxes in field settings (Dumortier et al., 2019). We performed the footprint analysis on a grid of $1 \mathrm{~m}$ pixels and aggregated values to the $20 \times 20 \mathrm{~m}$ grid to which the bison locations were estimated (Figure 1); Figure 3 demonstrates an example of a flux footprint for a single half-hourly period.

\subsection{Per-bison methane flux estimation}

Given that mean methane emissions were not significantly different from zero in the absence of bison - as detailed in Results - we assume that observed methane emissions are due to bison in the flux footprint. The relative contribution of bison to each half-hourly eddy covariance measurement was calculated by expanding the approach of Dumortier et al. (2019). From the definition of the footprint function, the measured density of a scalar $X, F_{X}$, for our study area of $8 \times 12$ grid cells (Figure 1 ) is:

$$
F_{X}=\sum_{i=1}^{8} \sum_{j=1}^{12} F_{i j} \phi_{i j} \Delta x_{i j} \Delta y_{i j}
$$

135 where $\phi_{i j}$ is the value of the footprint function in grid cell $i j$ (here per $400 \mathrm{~m}^{2}$ ) and $x$ and $y$ are the dimensions of the $20 \mathrm{~m}$ grid cells. Dumortier et al. (2019) considered a known point source from a single cell, $f_{X}$, such that:

$$
f_{X}=\frac{F_{X}}{\phi_{i j, \text { source }}}
$$

where $\phi_{i j, \text { source }}$ is the value of the footprint function at the source location. We have $N=40$ sources (i.e. bison) that are free to wander to any grid cell $i j$. We also have no basis for identifying individual bison given the resolution of the cameras, noting that this is possible using higher-resolution cameras ( Merkle and Fortin, 2013). We also have no basis for determining if the methane sources of individual bison are different using our approach, so we must assume that methane efflux from each bison is equal. Under these assumptions we can write:

$$
\left\langle f_{x}\right\rangle=\frac{F_{X}}{\sum_{i=1}^{8} \sum_{j=1}^{12} N_{i j} \phi_{i j} \Delta x_{i j} \Delta y_{i j}}
$$

Where $N_{i j}$ is the number of bison in grid cell $i j$ (i.e. per $400 \mathrm{~m}^{-2}$ ) and $\left\langle f_{x}\right\rangle$ is the average flux per bison. We only adopt this approach for calculating average methane efflux per bison as measured $\mathrm{CO}_{2}$ fluxes in the absence of bison were greater than zero.

\subsection{Spatial uncertainty}

The distribution of bison in the pasture was approximated visually using five-minute photographs and aggregated to halfhourly flux measurement periods, resulting in spatial uncertainty in bison location. To address spatial uncertainty, we shifted 
https://doi.org/10.5194/bg-2020-38

Preprint. Discussion started: 25 February 2020

(c) Author(s) 2020. CC BY 4.0 License.

(c) (i)

simulated bison positions within the footprint matrices by $20 \mathrm{~m}$, i.e. one grid square, in each cardinal direction. This was done to explore the possibility that an observer attempting to quantify the position of bison may tend to err in one particular direction or, alternatively, that the flux footprint calculation has a systematic bias in any one direction. We also tested if bison locations were more distributed than our visual estimates suggested due to small movements within half-hourly periods and due to the size of the animals themselves with reference to the grid scale. We created a more distributed estimates of bison locations using two-dimensional Tikhonov Regularization as described in Stoy and Quaife (2015). We applied the Tikhonov Regularization approach to each bison distribution map using Lagrange multipliers (related to the smoothness of the 155 distribution) that ranged from 0.1 to 4 as demonstrated for a single half-hour period in Figure 4 . All of our results are subject to simultaneous uncertainties in footprint and bison location in addition to the eddy covariance methane flux measurements themselves, which range from $6-41 \%$ for half-hourly fluxes and $7-17 \%$ for long-term sums (Deventer et al., 2019).

\section{Results}

\section{$160 \quad 3.1$ Meteorology}

Air temperature averaged $-2.8{ }^{\circ} \mathrm{C}$ and soil temperature averaged $-0.3{ }^{\circ} \mathrm{C}$ during the measurement period (Figure $5 \mathrm{~A}$ ). Incident shortwave radiation ranged between 100 and $400 \mathrm{~W} \mathrm{~m}^{-2}$ during peak daylight hours (1000-1400 hours local time) across the study period, and clear conditions were common except for four weeks beginning in mid-December (Figure 5B). Snow depth within the tower enclosure increased from $0.15 \mathrm{~m}$ to nearly $0.4 \mathrm{~m}$ in late 2017 and decreased to $0.1 \mathrm{~m}$ beginning in late January

1652018 (Figure 5C) noting that snow outside of the electrified tower enclosure was often trampled (see Figure 2). The median wind direction was $208^{\circ}$ and the footprint distribution during the entire measurement period shows a primary peak approximately $50 \mathrm{~m} \mathrm{SSW}$ of the tower and a secondary peak approximately $30 \mathrm{~m}$ north of the tower (Figure 6).

\subsection{Gas flux}

Half-hourly methane fluxes averaged $0.048 \pm 0.081 \mu \mathrm{mol} \mathrm{m}^{-2} \mathrm{~s}^{-1}$ (mean \pm standard deviation) and carbon dioxide fluxes averaged $1.6 \pm 1.4 \mu \mathrm{mol} \mathrm{m}^{-2} \mathrm{~s}^{-1}$ when bison were present (Figure 7), noting again that measurements were made only during daytime periods. Methane flux in the absence of bison averaged -.0009 $\pm 0.008 \mu \mathrm{mol} \mathrm{m} \mathrm{m}^{-2} \mathrm{~s}^{-1}$ and carbon dioxide flux averaged $0.64 \pm 1.0 \mu \mathrm{mol} \mathrm{m} \mathrm{m}^{-2} \mathrm{~s}^{-1}$, significantly lower than when bison were present $\left(P<0.001\right.$ for both $\mathrm{CH}_{4}$ and $\left.\mathrm{CO}_{2}\right) . \mathrm{CO}_{2}$ flux was significantly related to methane flux and explained $52 \%$ of its variance when bison were present but only $7 \%$ when they were absent (Figure 8 ). $\mathrm{CO}_{2}$ flux was significantly and positively related to air and soil temperature across the entire measurement 175 record $(P<0.001$ in both cases), but methane flux was not. There were no significant temporal patterns of methane flux during the daytime periods investigated here, and neither incident nor net radiation were related to methane fluxes. Methane flux was significantly and positively related to friction velocity in the absence of bison at $u^{*}$ values greater than $0.2 \mathrm{~m} \mathrm{~s}^{-1}(P=0.003)$ but not positively related to $u^{*}$ values less than $0.2 \mathrm{~m} \mathrm{~s}^{-1}$, indicating that flux measurements were unrelated to friction velocity values commonly associated with insufficient turbulence (Figure 9A). Carbon dioxide flux was not related to $u^{*}$ in the absence 
https://doi.org/10.5194/bg-2020-38

Preprint. Discussion started: 25 February 2020

(c) Author(s) 2020. CC BY 4.0 License.

(c) (i)

180 of bison (Figure 9B) but negative values were observed at $u^{*}$ values greater than $0.45 \mathrm{~m} \mathrm{~s}^{-1}$. Given these observations, we did not apply a $u *$ filter to our eddy covariance measurements, which were made only during daytime periods. We discuss potential reasons for the observed increase in methane flux and negative $\mathrm{CO}_{2}$ flux with high values of $u *$ in the Discussion section.

\subsection{Bison location and methane attribution}

Timelapse camera footage yielded usable imagery for 444 half-hourly periods. Bison tended to aggregate in an area on the

185 west side of the pasture near the location where supplemental hay was often provided (Figure 10). They tended to visit the interior of the pasture north of the tower in mornings and afternoons and often made sporadic mass movements to the southernmost edge of the field near its gate during the morning and midday periods (Figure 10).

Simultaneous camera and eddy covariance measurements were available during 173 half hourly periods after applying eddy covariance quality control filters. Per-bison methane emission estimates had a mean of $38 \pm 44 \mu \mathrm{mol} \mathrm{s}^{-1}$ bison $^{-1}$ and a median

190 of $22 \mu \mathrm{mol} \mathrm{s}^{-1}$ bison $^{-1}$ as a result of the positively skewed measurement distribution (Figure 11). Shifting the bison location estimates $20 \mathrm{~m}$ in all cardinal directions resulted in a range of mean per-bison methane emission estimates of $36-44 \mu \mathrm{mol} \mathrm{s}$

${ }^{1}$ bison $^{-1}$, a mean change of no more than $16 \%$ (Table 1). Spatial smoothing using the Tikhonov Regularization analysis resulted in a range of mean methane efflux estimates from $36-44 \mu \mathrm{mol} \mathrm{s}^{-1}$ bison $^{-1}$ (Figure 12), a mean change of no more than $21 \%$. If we adopt $21 \%$ as a conservative uncertainty estimate due to spatial uncertainty and $17 \%$ as a conservative uncertainty 195 estimate of long-term methane flux sums (Deventer et al., 2019), we arrive at a daily per-bison methane flux estimate of $52 \pm$ $14 \mathrm{~g} \mathrm{CH}_{4} \mathrm{~m}^{-2}$ day $^{-1}$.

\section{Discussion}

The eddy covariance flux footprint analysis coupled to bison location estimates from automated camera images resulted in a mean (median) methane flux of $38 \mu \mathrm{mol} \mathrm{s}{ }^{-1}\left(22 \mu \mathrm{mol} \mathrm{s}^{-1}\right)$ per animal that is sensitive to spatial uncertainty (Table 1, Figure 12). If we assume that methane flux from bison varies negligably by season, a notion that needs to be substantiated, our measurements with conservative uncertainty estimates correspond to $19 \pm 5$ kilograms of methane per bison per year, noting that methane emissions from cattle have been observed to be on the order of $10 \%$ higher in summer than winter (Todd et al., 2014). Previous estimates of methane emissions from range cattle are on the order of $60 \mathrm{~kg}$ per year per animal (Hogan, 1993), 205 some three times larger than the mean per-bison methane flux calculated here.

\subsection{Bison methane and carbon dioxide efflux in response to environmental variables}

Methane flux was not related to air or soil temperature but was related to $u^{*}$ - especially at relatively high values of $u^{*}-$ in the absence of bison (Figure 9). These observations are consistent with a potential pressure pumping mechanism for trace gases through snow at higher wind speeds (Bowling and Massman, 2011) although it is unclear why this relationship exists

210 for methane flux and not carbon dioxide flux as is frequently found in snow-covered conditions (Rains et al., 2016). Carbon 
https://doi.org/10.5194/bg-2020-38

Preprint. Discussion started: 25 February 2020

(c) Author(s) 2020. CC BY 4.0 License.

\section{(c) (i)}

dioxide flux at high values of $u^{*}$ was positive indicating net $\mathrm{CO}_{2}$ uptake by the biosphere, which is unlikely in our study site during winter suggesting that values with excessively high $u^{*}$ may need to be filtered, but with only five observations of $\mathrm{CO}_{2}$ flux less than zero it is unclear how to apply such a filter.

Insufficient evidence exists in our data record to attribute observed methane efflux to the onset of freezing conditions in soil

215 (Mastepanov et al., 2008). We note that extensive snow trampling (e.g., Figure 2) likely resulted in a situation where snow depth (Figure 5D) and its insulating effect on soil temperature (Figure 5A) varied across the field and therefore differed from measurements taken by within the instrumentation enclosure. Regardless, mean methane flux when bison were absent and $u^{*}$ exceeded $0.3 \mathrm{~m} \mathrm{~s}^{-1},-0.0009 \mu \mathrm{mol} \mathrm{m} \mathrm{m}^{-2} \mathrm{~s}^{-1}$, was nearly two orders of magnitude less than the mean methane flux when bison were present, $0.041 \mu \mathrm{mol} \mathrm{m} \mathrm{m}^{-2} \mathrm{~s}^{-1}$. Whereas we cannot exclude - and in fact expect - positive and negative background methane

220 fluxes from non-bison sources in a grassland in winter in the vicinity of a riparian area (Figure 1, Merbold et al., 2013; McLain and Martens, 2006; Mosier et al., 1991), these appear to be minor compared to the $\mathrm{CH}_{4}$ flux attributable to bison (Figures 7 and 8). Bison are associated with a distinct methane flux signature as shown by the immediate decline of methane fluxes following their removal from the study pasture (Figure 7) and strong relationship with carbon dioxide flux (Figure 8) given the common source of respiration and most enteric methane losses from the mouths of ungulates. Methane flux was related to

225 carbon dioxide flux when bison were present or absent (Figure 8), suggesting both soil and ruminant sources (and in the case of methane sinks) of both gases (Baldocchi et al., 2012; Motte et al., 2019). It is important to note that potential methane fluxes from bison manure may have been dampened by freezing conditions but are an important methane source during warmer conditions in ruminant grazing systems (Dengel et al., 2011). Manure is thought to contribute a nontrivial portion (10-14 Tg $\mathrm{CH}_{4} \mathrm{yr}^{-1}$ ) of total ruminant methane efflux (77 $\mathrm{Tg} \mathrm{CH}_{4} \mathrm{yr}^{-1}$, Johnson and Ward 1996; Moss et al., 2000) noting that some farm-

230 scales studies arrive at lower percentages (Taylor et al., 2017). Though we did not observe higher methane efflux early in the study period when soil temperature was above freezing nor temperature sensitivity of methane efflux in the presence or absence of bison, it is important to note that field-scale methane efflux may be diminished by the thermal environment of manure in our measurements.

\subsection{Bison spatial distribution}

235 The spatial distribution of bison in the study pasture varied from morning to midday and afternoon (Figure 10). It is difficult to infer from the available data whether the study bison are more active during morning and evening hours in the pasture environment like cattle (Gregorini 2012). Supplemental hay was made available to the bison in the grid square approximately 50 meters west of the tower and increases in the frequency of bison appearance there are likely associated with the animals' preferred feeding times after dawn and before dusk, when there is tentative evidence of greater mean per-bison methane flux 240 but patterns are not significant (Figure 13). There may also be evidence from the diurnal course of methane measurements that bison show a diurnal methane flux signature that is consistent with metabolic activity, like sheep (Dengel et al., 2011), given the minor per-bison methane efflux peak around noon. Regardless, ruminant methane flux measurements are simpler to make 
https://doi.org/10.5194/bg-2020-38

Preprint. Discussion started: 25 February 2020

(c) Author(s) 2020. CC BY 4.0 License.

\section{(c) (i)}

when animals congregate (Coates et al., 2017; Tallec et al., 2012) and ruminant behavior is critical to track to estimate fieldscale efflux (de la Motte et al., 2019). Aggregation behavior in our study bison herd was often upwind of the eddy covariance tower (Figures $6 \& 11$ ) and resulted in more overlap between flux footprint and bison location than would have occurred if bison locations were randomly distributed throughout the study area, emphasizing the importance of tower placement in studies of grazing systems.

Spatial uncertainties in bison location interact with uncertainties in flux footprint modelling for methane source attribution (Table 1). Analytical footprint models like the one used here have been found to accurately estimate point sources of trace gas flux (Dumortier et al., 2019), but it is important to note that footprint modelling techniques play a large role in the spatial attribution of observed fluxes of ruminant trace gas flux (Felber et al., 2015). Prajapati and Santos (2018), for instance, found that an analytical model (Kormann and Meixner 2001) predicted flux footprint areas five to six times larger than did an approximation of a Lagrangian dispersion model (Kljun et al., 2003), such that footprint model uncertainty is a major source of uncertainty for measuring methane flux from multiple point sources. When we shift the footprint model to account for spatial uncertainty, the resulting mean methane flux of up to $43 \mu \mathrm{mol} \mathrm{bison} \mathrm{s}^{-1} \mathrm{~s}^{-1}$ (Table 1) corresponds to a flux of $22 \mathrm{~kg}$ per animal per year, still far less than established flux estimates from range cattle of $60 \mathrm{~kg}$ per year per animal (Hogan, 1993). In other words, while there is no evidence from our measurements that bison have more methane efflux than typical values reported for cattle, it is critical to make full year-round methane flux measurements with uncertainty to understand the seasonal course of bison methane efflux to establish defensible annual sums.

\subsection{Future directions for greenhouse gas accounting in ruminant grazing systems}

Methane efflux cannot be completely removed from ruminant grazing systems; some $4.6-6.2 \%$ of gross energy intake is lost as methane in cattle, sheep and goats worldwide (Johnson and Ward 1996) with cattle often falling on the higher end of the observed range (Lassey et al., 1997). But there are other aspects of bison ecology that merit consideration when designing greenhouse gas-cognizant grazing systems. For example, cattle tend to graze close to water more frequently than do bison

265 (Allred et al., 2011) with unclear consequences for riparian vegetation, water quality, and potential methane efflux from cattle wallows. Cattle also tend to graze for longer periods than bison (Plumb and Dodd, 1993) and it is unclear if there is an associated consequence for methane efflux. Future work should consider the large inter-animal variability in methane efflux (Lassey et al., 1997), possibly through the use of advanced techniques for identifying individual animals through photographs (Merkle and Fortin, 2013) or tracking devices (Felber et al., 2015). Predicted increases in atmospheric carbon dioxide concentrations are likely to decrease forage quality (Jégo et al., 2013), resulting in higher leaf carbon to nitrogen ratios and cellulose content which is expected to increase ruminant methane emissions (Lee et al., 2017), all else being equal. Adding seasonal foraging behavior, estimating emissions from individual animals, and addressing seasonal and inter-annual variability and trends in forage nutrition are likely to further improve prediction of methane emissions from grazing systems (Moraes et al., 2013). Advanced eddy covariance algorithms for are also likely to improve flux estimates on short time scales noting that 
https://doi.org/10.5194/bg-2020-38

Preprint. Discussion started: 25 February 2020

(c) Author(s) 2020. CC BY 4.0 License.

(c) (i)

275 non-stationary bursts have not been found to create systematic bias in methane budgets measured over longer time periods using eddy covariance (Göckede et al., 2019). Ongoing interest in bison reintroduction and ungulate ecology coupled with established micrometeorological measurement techniques will help us understand the present and future role that bison and alternative grazing systems play in the Earth system.

\section{Acknowledgements}

PCS acknowledges support from the U.S. National Science Foundation awards DEB-1552976 and OIA-1632810, the USDA National Institute of Food and Agriculture Hatch project 228396, the Multi-State project W3188, the Graduate School at Montana State University, and the University of Wisconsin - Madison. Funding for the LI-7700 methane analyzer used in this work was provided to JED by NSF-EPSCoR award EPS-1101342 and Montana State University. Daniel Salinas, Gabriel

285 Bromley, Zheng Fu, and James Irvine provided technical assistance. This work could not have been completed without permission of Turner Enterprises, Inc. and the assistance of Carter Kruse and Danny Johnson.

\section{Code/Data availability}

Data will be made available on scholarworks.montana.edu upon acceptance of the manuscript.

\section{Author contributions}

PCS designed the study with AC, JD, and WK and wrote the manuscript with AC and all coauthors. AC collected and analyzed data with PCS and TG assisted with flux data analysis.

\section{Competing interests}

The authors declare no competing interests.

\section{References}

Allred, B. W., Fuhlendorf, S. D. and Hamilton, R. G.: The role of herbivores in Great Plains conservation: comparative 300 ecology of bison and cattle. Ecosphere 2(3), 26, 2011.

Baldocchi, D. D., Detto, M., Sonnentag, O., Verfaillie, J., Teh, Y. A., Silver, W. and Kelley, N. M.: The challenges of measuring methane fluxes and concentrations over a peatland pasture. Agric. For. Met. 153, 177-187, 2012.

Beauchemin, K. A., Kreuzer, M., O’Mara, F. and McAllister, T. A.: Nutritional management for enteric methane abatement: a review, Aust. J. Exp. Agric., 48(2), 21-27, 2008.

305 Boadi, D. A. and Wittenberg, K. M.: Methane production from dairy and beef heifers fed forages differing in nutrient density using the sulphur hexafluoride ( $\mathrm{SF}_{6}$ ) tracer gas technique. Can. J. Anim. Sci., 82, 201-206, 2002. 
https://doi.org/10.5194/bg-2020-38

Preprint. Discussion started: 25 February 2020

(c) Author(s) 2020. CC BY 4.0 License.

(c) (i)

Bowling, D. R. and Massman, W. J.: Persistent wind-induced enhancement of diffusive $\mathrm{CO}_{2}$ transport in a mountain forest snowpack. J. Geophys. Res. 116, 1-15, 2011.

Chappellaz, J. A., Fung, I. Y. and Thompson A. M.: The atmospheric $\mathrm{CH}_{4}$ increase since the Last Glacial Maximum. Tellus

310 B, 45(3), 228-241, 1993.

Chaves, A. V., Thompson, L., C., Iwaasa, A., D., Scott, S., L., Olson, M. E., Benchaar, C., Veira, D., M. and McAllister, T., A.: Effect of pasture type (alfalfa vs. grass) on methane and carbon dioxide production by yearling beef heifers. Can. J.

Anim. Sci., 86, 409-418, 2006.

Coates, T., W., Benvenutti, M. A., Flisch, T. K., Charmley, E., McGinn, S. M. and Chen D.: Applicability of eddy

315 covariance to estimate methane emissions from grazing cattle. J. Environ. Qual. 47(1), 54-61, 2017.

Collins, S.L. and Steinauer, E.M.: Disturbance, diversity and species interactions in tallgrass prairie. In: Knapp AK, Briggs

JM, Hartnett DC, Collins SC (ed) Grassland Dynamics: Long-Term Ecological Research in Tallgrass Prairie. Oxford

University Press, pp 140-156, 1998.

Coppedge, B. R. and Shaw, J. H.: Bison grazing patterns on seasonally burned tallgrass prairie. J. Range Manage. 51, 258-

$320264,1998$.

de la Motte, L. G., Dumortier, P., Beckers, Y., Bodson, B., Heinesch, B. and Aubinet, M.: Herd position habits can bias net $\mathrm{CO}_{2}$ ecosystem exchange estimates in free range grazed pastures, Agric. For. Met., 268, 156-168, 2019.

Dengel, S., Levy, P. E., Grace, J., Jones, S. K. and Skiba, U. M.: Methane emissions from sheep pasture, measured with an open-path eddy covariance system, Glob. Chang. Biol., 17(12), 3524-3533, 2011.

325 DeRamus, H.A., Clement, T.C., Giampola, D.D. and Dickison, P.C.: Methane emissions of beef cattle on forages. J.

Environ. Qual.: 32(1), 269-277, 2003.

Detto, M. and Katul, G. G.: Simplified expressions for adjusting higher-order turbulent statistics obtained from open path gas analyzers, Bound.-Layer Meteorol., 122(1), 205-216, 2006.

Detto, M., Verfaillie, J., Anderson, F., Xu, L. and Baldocchi, D.: Comparing laser-based open- and closed-path gas analyzers

330 to measure methane fluxes using the eddy covariance method, Agric. For. Meteorol., 151(10), 1312-1324, 2011.

FAO: Global Livestock Environmental Assessment Model (GLEAM). Rome, 2017.

Deventer, M. J., Deventer, M., Griffis, T. J., Roman, D., Kolka, R. K., Wood, J. D., Erickson, M., Baker, J. M. and Millet, D.

B.: Error characterization of methane fluxes and budgets derived from a long-term comparison of open- and closed-path eddy covariance systems, Agricultural and Forest Meteorology, 278, 107638, 2019.

335 Dumortier, P., Aubinet, M., Lebeau, F., Naiken, A. and Heinesch, B.: Point source emission estimation using eddy covariance: Validation using an artificial source experiment. Agric. For. Meteorol., 266-267, 148-156, 2019.

Felber, R., Münger, A., Neftel, A. and Ammann, C.: Eddy covariance methane flux measurements over a grazed pasture: effect of cows as moving point sources, Biogeosciences, 12(12), 3925-3940, 2015.

Flores D: Bison ecology and bison diplomacy: The southern plains from 1800 to 1850. J Am Hist 78:465-485, 1991. 
https://doi.org/10.5194/bg-2020-38

Preprint. Discussion started: 25 February 2020

(c) Author(s) 2020. CC BY 4.0 License.

(c) (i)

340 Fortin, D., Fryxell, J. M., O’Brodovich, L. and Frandsen, D.: Foraging ecology of bison at the landscape and plant community levels: the applicability of energy maximization principles, Oecologia, 134(2), 219-227, 2003.

Freese, C. H., Aune, K. E., Boyd, D. P., Derr, J. N., Forrest, S. C., Gates, C. C., Gogan, P. J. P., Grassel, S. M., Halbert, N., D., Kunkel, K. and Redford, K., H.: Second chance for the plains bison. Biological Conservation, 136(2), 175-184, 2007. Galbraith, J. K., Mathison, G. W., Hudson, R. J., McAllister, T. A. and Cheng, K.-J.: Intake, digestibility, methane and heat 345 production in bison, wapiti and white-tailed deer, Can. J. Anim. Sci., 78(4), 681-691, 1998.

Foken T., Göckede, M., Mauder, M., Mahrt, L., Amiro, B. and Munger W.: Post-field data quality control. In Lee, X., Massman, W.J. and Law, B. (eds) Handbook of micrometeorology: A guide for surface flux measurement and analysis. Kluwer, Dordrecht, The Netherlands, 2004.

Gates, C. C., Freese, C. H., Gogan, P. J. and Kotzman M (eds): American bison: status survey and conservation guidelies 350 2010. IUCN, 2010.

Gerber, P.J., Steinfeld, H., Henderson, B., Mottet, A., Opio, C., Dijkman, J., Falcucci, A. and Tempio, G.: Tackling climate change through livestock - A global assessment of emissions and mitigation opportunities. Food and Agriculture Organization of the United Nations (FAO), Rome, 2013.

Geremia, C, Merkle, J.A., Eaker, D.R., Wallen, R.L., White, P.J., Hebblewhite, M. and Kaufman, M.J.: Migrating bison

355 engineer the green wave. Proc. Nat. Acad. Sci.: 116(51), 25707-25713, 2019.

Gregorini, P. Diurnal grazing pattern: its physiological basis and strategic management. Animal Production Science 52.7: 416-430, 2012.

Göckede, M., Kittler, F. and Schaller, C.: Quantifying the impact of emission outbursts and non-stationary flow on eddycovariance $\mathrm{CH}_{4}$ flux measurements using wavelet techniques, Biogeosciences, 16, 3113-3131, 2019.

360 Hanson, J.R.: Bison ecology in the Northern Plains and a reconstruction of bison patterns for the North Dakota region. Plains Anthropol., 93-113, 1984.

Hartnett, D.C., Hickman, K.R. and Fischer, W.L.E.: Effects of bison grazing, fire, and topography on floristic diversity in tallgrass prairie. J. Range. Manage., 49, 413-420, 1996.

Hedrick, P. W.: Conservation genetics and North American bison (Bison bison), J. Hered., 100(4), 411-420, 2009.

365 Hogan, K. B.: Anthropogenic methane emissions in the United States: Estimates for 1990. National Service Center for Environmental Publications, 1993.

Herrero, M., Henderson, B., Havlík, P., Thornton, P. K., Conant, R. T., Smith, P., Wirsenius, S., Hristov, A. N., Gerber, P., Gill, M., Butterbach-Bahl, K., Valin, H., Garnett, T. and Stehfest, E.: Greenhouse gas mitigation potentials in the livestock sector, Nature Climate Change, 6(5), 452-461, doi:10.1038/nclimate2925, 2016.

370 Hristov, A.N.: Historic, pre-European settlement, and present-day contribution of wild ruminants to enteric methane emissions in the United States. J. Animal Sci.: 90(4), 1371-1375, 2012.

Hristov, A. N., Oh, J., Firkins, J. L., Dijkstra, J., Kebreab, E., Waghorn, G., Makkar, H. P. S., Adesogan, A. T., Yang, W., Lee, C., Gerber, P. J., Henderson, B. and Tricarico, J. M.: Special topics - Mitigation of methane and nitrous oxide 
https://doi.org/10.5194/bg-2020-38

Preprint. Discussion started: 25 February 2020

(c) Author(s) 2020. CC BY 4.0 License.

(c) (i)

emissions from animal operations: I. A review of enteric methane mitigation options, Journal of Animal Science, 91(11),

5045-5069, doi:10.2527/jas.2013-6583, 2013.

Hsieh, C.-I., Katul, G. and Chi, T.-W.: An approximate analytical model for footprint estimation of scalar fluxes in thermally stratified atmospheric flows, Adv. Water Resour., 23(7), 765-772, 2000.

Isenberg, A.C. The Destruction of the Bison: An Environmental History, 1750-1920. Cambridge Univ Press, Cambridge, UK, 2000.

380 Jégo, G., Bélanger, G., Tremblay, G. F., Jing, Q. and Baron, V. S.: Calibration and performance evaluation of the STICS crop model for simulating timothy growth and nutritive value, Field Crops Res., 151, 65-77, 2013.

Johnson, K. A. and Johnson, D. E.: Methane emissions from cattle. J. Anim. Sci., 73, 2483-2491, 1995.

Johnson, D. E. and Ward, G. M.: Estimates of animal methane emissions. Environ. Monit. Assess., 42, 133-141, 1996.

Kelliher, F. M. and Clark, H.: Methane emissions from bison—An historic herd estimate for the North American Great

385 Plains, Agric. For. Meteorol., 150(3), 473-477, 2010.

Kirschke, S., Bousquet, P., Ciais, P., Saunois, M., Canadell, J. G., Dlugokencky, E. J., Bergamaschi, P., Bergmann, D.,

Blake, D. R., Bruhwiler, L., Cameron-Smith, P., Castaldi, S., Chevallier, F., Feng, L., Fraser, A., Heimann, M., Hodson, E.

L., Houweling, S., Josse, B., Fraser, P. J., Krummel, P. B., Lamarque, J.-F., Langenfelds, R. L., Le Quéré, C., Naik, V., O’Doherty, S., Palmer, P. I., Pison, I., Plummer, D., Poulter, B., Prinn, R. G., Rigby, M., Ringeval, B., Santini, M., Schmidt,

390 M., Shindell, D. T., Simpson, I. J., Spahni, R., Steele, L. P., Strode, S. A., Sudo, K., Szopa, S., van der Werf, G. R., Voulgarakis, A., van Weele, M., Weiss, R. F., Williams, J. E. and Zeng, G.: Three decades of global methane sources and sinks, Nat. Geosci., 6(10), 813-823, 2013.

Kljun, N., Kormann, R., Rotach, M. W. and Meixner, F. X.: Comparison of the Langrangian Footprint, Bound.-Layer Meteorol., 106(2), 349-355, 2003.

395 Knapp, A. K., Blair, J. M., Briggs, J. M., Collins, S. L., Hartnett, D. C., Johnson, L. C. and Towne, G. E.: The keystone role of bison in North American tallgrass prairie, Bioscience, 49(1), 39, 1999.

Kormann, R. and Meixner F. X.. An analytical footprint model for non-neutral stratification. Bound.-Layer Meteorol., 99(2), 207-224, 2001.

Lashof, D. A. and Ahuja, D. R.: Relative contributions of greenhouse gas emissions to global warming, Nature, 344(6266),

400 529-531, 1990.

Lassey, K. R., Ulyatt, M. J., Martin, R. J., Walker, C. F. and Shelton, I., D.: Methane emissions measured directly from grazing livestock in New Zealand. Atmos. Environ. 31, 2905-2914, 1997.

Lee, M. A., Davis, A. P., Chagunda, M. G. G. and Manning, P.: Forage quality declines with rising temperatures, with implications for livestock production and methane emissions, Biogeosciences, 14, 1403-1417, 2017.

405 Mastepanov, M., Sigsgaard, C., Dlugokencky, E. J., Houweling, S., Ström, L., Tamstorf, M. P. and Christensen, T. R.: Large tundra methane burst during onset of freezing. Nature, 456, 628-631, 2008.

Mauder, M., and Foken, T.: Documentation and instruction manual of the eddy-covariance software package TK3, 2011. 
https://doi.org/10.5194/bg-2020-38

Preprint. Discussion started: 25 February 2020

(c) Author(s) 2020. CC BY 4.0 License.

(c) (i)

McLain, J.E. and Martens, D.A.: Moisture controls on trace gas fluxes in semiarid riparian soils. Soil Sci. Soc. Am. J. 70(2), 367-77, 2006.

410 Merbold, L., Steinlin, C. and Hagedorn, F.: Winter greenhouse gas fluxes $\left(\mathrm{CO}_{2}, \mathrm{CH}_{4}\right.$ and $\left.\mathrm{N}_{2} \mathrm{O}\right)$ from a subalpine grassland. Biogeosciences. 10(5), 3185-3203, 2013

Merkle, J. A. and Fortin D.: Likelihood-based photograph identification: Application with photographs of free-ranging bison. Wild. Soc. Bull., 38, 196-204, 2014.

Moncrieff, J., Clement, R., Finnigan, J., and Meyers, T.: Averaging, detrending, and filtering of eddy covariance time series.

415 In Lee, X., Massman, W.J. and Law, B. (eds) Handbook of Micrometeorology. Springer, Dordrecht, 7-31, 2004.

Moncrieff, J.B., Massheder, J.M., De Bruin, H., Elbers, J., Friborg, T., Heusinkveld, B., Kabat, P., Scott, S., Søgaard, H., and Verhoef, A.: A system to measure surface fluxes of momentum, sensible heat, water vapour and carbon dioxide. J.

Hydrology, 188, 589-611, 1997.

Moraes, L. E., Strathe, A. B., Fadel, J. G., Casper, D. P. and Kebreab, E.: Prediction of enteric methane emissions from

cattle. Glob. Change Biol., 20, 2140-2148, 2014.

Moe, P. W. and Tyrrell, H. F.: Methane production in dairy cows, J. Dairy Sci., 62(10), 1583-1586, 1979.

Mosier, A., Schimel, D., Valentine, D., Bronson, K. and Parton, W. Methane and nitrous oxide fluxes in native, fertilized and cultivated grasslands. Nature, 350(6316), 330-332, 1991.

Moss, A.R., Jouany, J.-P., and Newbold, J.: Methane production by ruminants: its contribution to global warming. Ann.

425 Zootech., 49, 231-253, 2000.

Nisbet, E. G., Manning, M. R., Dlugokencky, E. J., Fisher, R. E., Lowry, D., Michel, S. E., Lund Myhre, C., Platt, S. M., Allen, G., Bousquet, P., Brownlow, R., Cain, M., France, J. L., Hermansen, O., Hossaini, R., Jones, A. E., Levin, I., Manning, A. C., Myhre, G., Pyle, J. A., Vaughn, B. H., Warwick, N. J. and White, J. W. C.: Very strong atmospheric methane growth in the 4 Years 2014-2017: Implications for the Paris Agreement, Glob. Biogeochem. Cycles, 33(3), 318$430342,2019$.

Plumb, G. E. and Dodd J. L.: Foraging ecology of bison and cattle on a mixed prairie: implications for natural area management. Ecol. App. 3:631-643, 1993.

Prajapati, P. and Santos, E. A.: Estimating methane emissions from beef cattle in a feedlot using the eddy covariance technique and footprint analysis, Agric. For. Meteorol., 258, 18-28, 2018.

435 Rains, F. A., Stoy, P. C., Welch, C. M., Montagne, C. \& McGlynn, B. L.: A comparison of methods reveals that enhanced diffusion helps explain cold-season soil $\mathrm{CO}_{2}$ efflux in a lodgepole pine ecosystem. Cold Regions Science and Technology, 121, 16-24, 2016.

Sanderson, E.W., Redford, K.H., Weber, B., Aune, K., Baldes, D., Berger, J., Carter, D., Curtin, C., Derr, J., Bodrott, S., Fearn, E., Fleener, C., Forrest, S., Gerlach, C., Gates, C. C. Gross, J. E., Gogan, P., Grassel, S., Hilty, J.A., Jensen, M., 440 Kunkel, K., Lammers, D., List, R., Minowski, K., Olson, T., Pague, C., Robertson, P. and Stephenson, B.: The ecological 
https://doi.org/10.5194/bg-2020-38

Preprint. Discussion started: 25 February 2020

(c) Author(s) 2020. CC BY 4.0 License.

(c) (i)

future of the North American Bison: Conceiving long-term, large-scale conservation of wildlife, Conservation Biology 22(2), 252-266, 2008.

Smith, F. A., Hammond, J. I., Balk, M. A., Elliott, S., M., Lyons, S., K., Pardi, M., I., Tomé, C. P., Wagner, P., J. and Westover, M., L.: Exploring the influence of ancient and historic megaherbivore extirpations on the global methane budget.

445 Proc. Natl. Acad. Sci. U. S. A., 113 (4), 874-879, 2016.

Smits, D. D.: The frontier army and the destruction of the buffalo: 1865-1883. West. Hist. Q., 25, 313-338, 1994.

Steuter, A. A. and Hidinger, L.: Comparative ecology of bison and cattle on mixed-grass prairie. Great Plains Research 9:329-342, 1999.

Stoy, P. C. and Quaife T.: Probabilistic downscaling of remote sensing data with applications for multi-scale biogeochemical

flux modeling. PLoS One, 10(6): e0128935, 2005.

Subak, S.: Methane from the House of Tudor and the Ming Dynasty: Anthropogenic emissions in the sixteenth century.

Chemosphere, 29(5), 843-854, 1994.

Sun, K., Tao, L., Miller, D. J., Zondlo, M. A., Shonkwiler, K. B., Nash, C. and Ham, J. M.: Open-path eddy covariance measurements of ammonia fluxes from a beef cattle feedlot, Agric. For. Meteorol., 213, 193-202, 2015.

455 Tallec, T., Klumpp, K., Hensen, A., Rochette, Y. and Soussana, J.-F.: Methane emission measurements in a cattle grazed pasture: a comparison of four methods. Biogeosciences Discussions, doi.org/10.5194/bgd-9-14407-2012, 2012.

Taylor, A. M., Amiro, B. D., Tenuta, M. and Gervais, M.: Direct whole-farm greenhouse gas flux measurements from a beef cattle operation. Agr. Ecosyst. Environ., 239, 65-79, 2017.

Thompson, A. M., Chappellaz, J. A., Fung, I. Y. and Kucsera, T. L.: The atmospheric $\mathrm{CH}_{4}$ increase since the Last Glacial

460 Maximum, Tellus B Chem. Phys. Meteorol., 45(3), 242-257, 1993.

Thornton, P. K. and Herrero, M.: Potential for reduced methane and carbon dioxide emissions from livestock and pasture management in the tropics, Proc. Natl. Acad. Sci. U. S. A., 107(46), 19667-19672, 2010.

Todd, R. W., Altman, M. B., Cole, N. A. and Waldrip, H. M.: Methane emissions from a beef cattle feedyard during winter and summer on the Southern High Plains of Texas, J. Environ. Qual., 43, 1125-1130, 2014.

465 Towne, E.G., Hartnett, D.C., Cochran, R.C.: Vegetation trends in tallgrass prairie from bison and cattle grazing, Ecol. Appl., $15,1550-1559,2005$.

Vickers, D. and Mahrt, L.: Quality control and flux sampling problems for tower and aircraft data, J. Atmos. Ocean.

Technol., 14(3), 512-526, 1997.

Vinton, M. A., Hartnett, D. C., Finck, E. J. and Briggs, J. M.: Interactive effects of fire, bison (Bison bison) grazing and plant

470 community composition in tallgrass prairie, Am. Midl. Nat., 129(1), 10, 1993.

Webb, E. K., Pearman, G. I. and Leuning, R.: Correction of flux measurements for density effects due to heat and water vapour transfer, Quarterly Journal of the Royal Meteorological Society, 106(447), 85-100, 1980.

Wolf, J., Asrar, G. R. and West, T. O.: Revised methane emissions factors and spatially distributed annual carbon fluxes for global livestock, Carbon Balance Manag., 12(1), 16, 2017. 
https://doi.org/10.5194/bg-2020-38

Preprint. Discussion started: 25 February 2020

(C) Author(s) 2020. CC BY 4.0 License.

(c) (i)

475 Zontek, K.: Buffalo Nation: American Indian Efforts to Restore the Bison, Bison Books., 2007. 
https://doi.org/10.5194/bg-2020-38

Preprint. Discussion started: 25 February 2020

(C) Author(s) 2020. CC BY 4.0 License.

(c) (1)

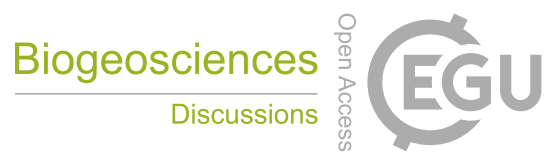

\section{Tables}

Table 1: The mean and standard deviation of per-bison methane fluxes and corresponding values after shifting the flux footprint matrix 20 meters in the direction indicated by the left column as a sensitivity analysis for bison location estimates.

\begin{tabular}{|l|l|}
\hline Footprint shift direction & \multicolumn{1}{|c|}{$\mu \mathrm{mol} \mathrm{s}^{-1}$ bison $^{-1}$} \\
\hline None & $38 \pm 44$ \\
\hline North & $43 \pm 47$ \\
\hline South & $41 \pm 50$ \\
\hline East & $36 \pm 42$ \\
\hline West & $37 \pm 51$ \\
\hline
\end{tabular}


https://doi.org/10.5194/bg-2020-38

Preprint. Discussion started: 25 February 2020

(c) Author(s) 2020. CC BY 4.0 License.

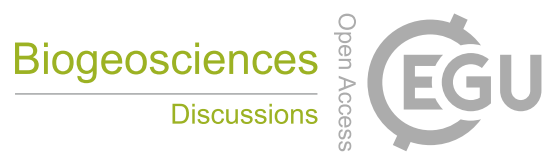

\section{Figures}

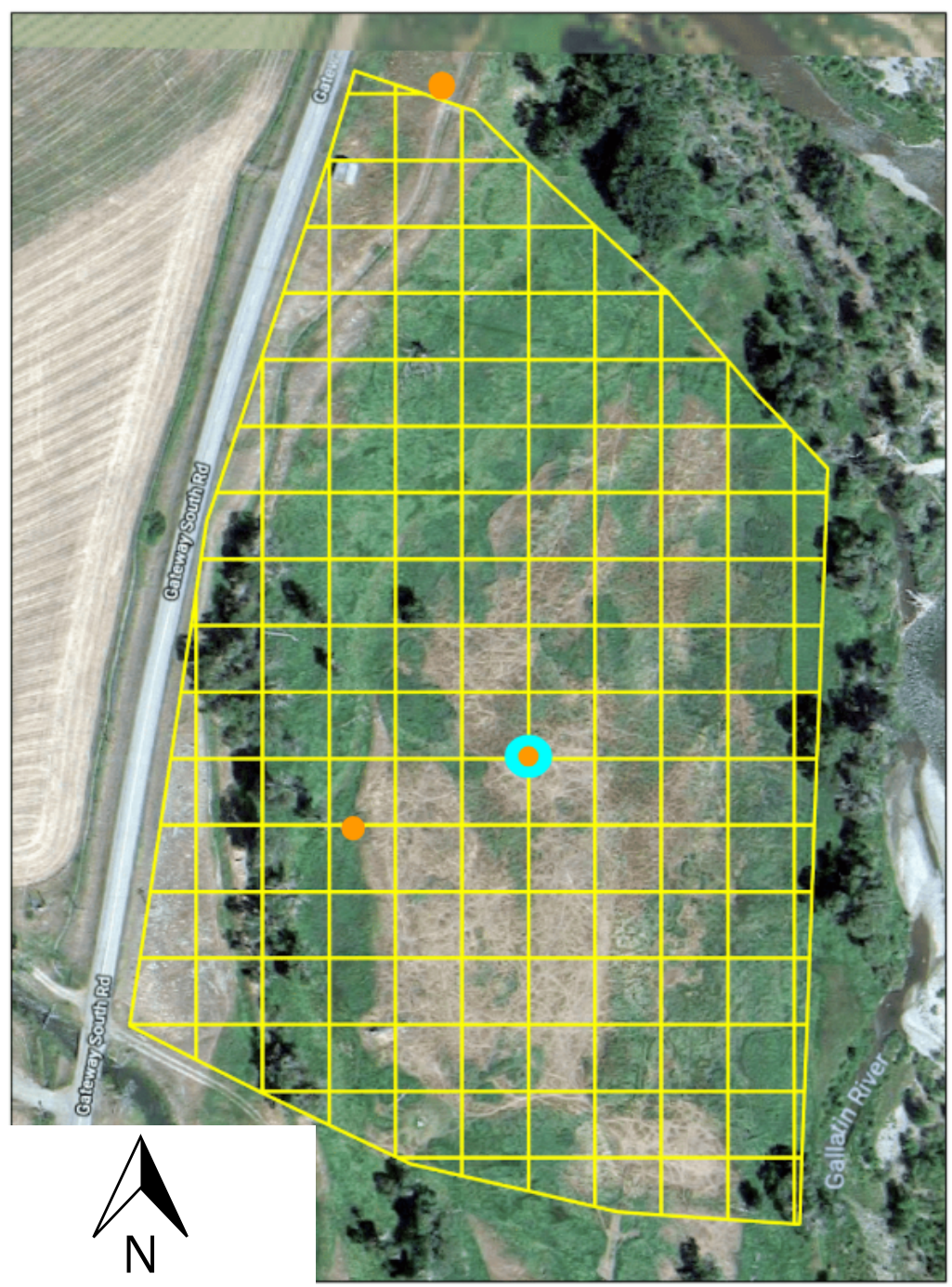

485 Figure 1: The study site near Gallatin Gateway, MT (45.557, -111.229). Bison locations are mapped within the 20-meter grid here superimposed in yellow. The tower location is in cyan and game camera locations are indicated in orange.

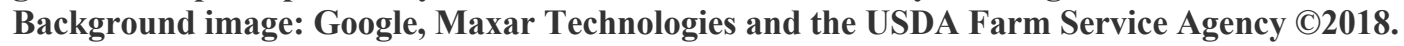


https://doi.org/10.5194/bg-2020-38

Preprint. Discussion started: 25 February 2020

(C) Author(s) 2020. CC BY 4.0 License.
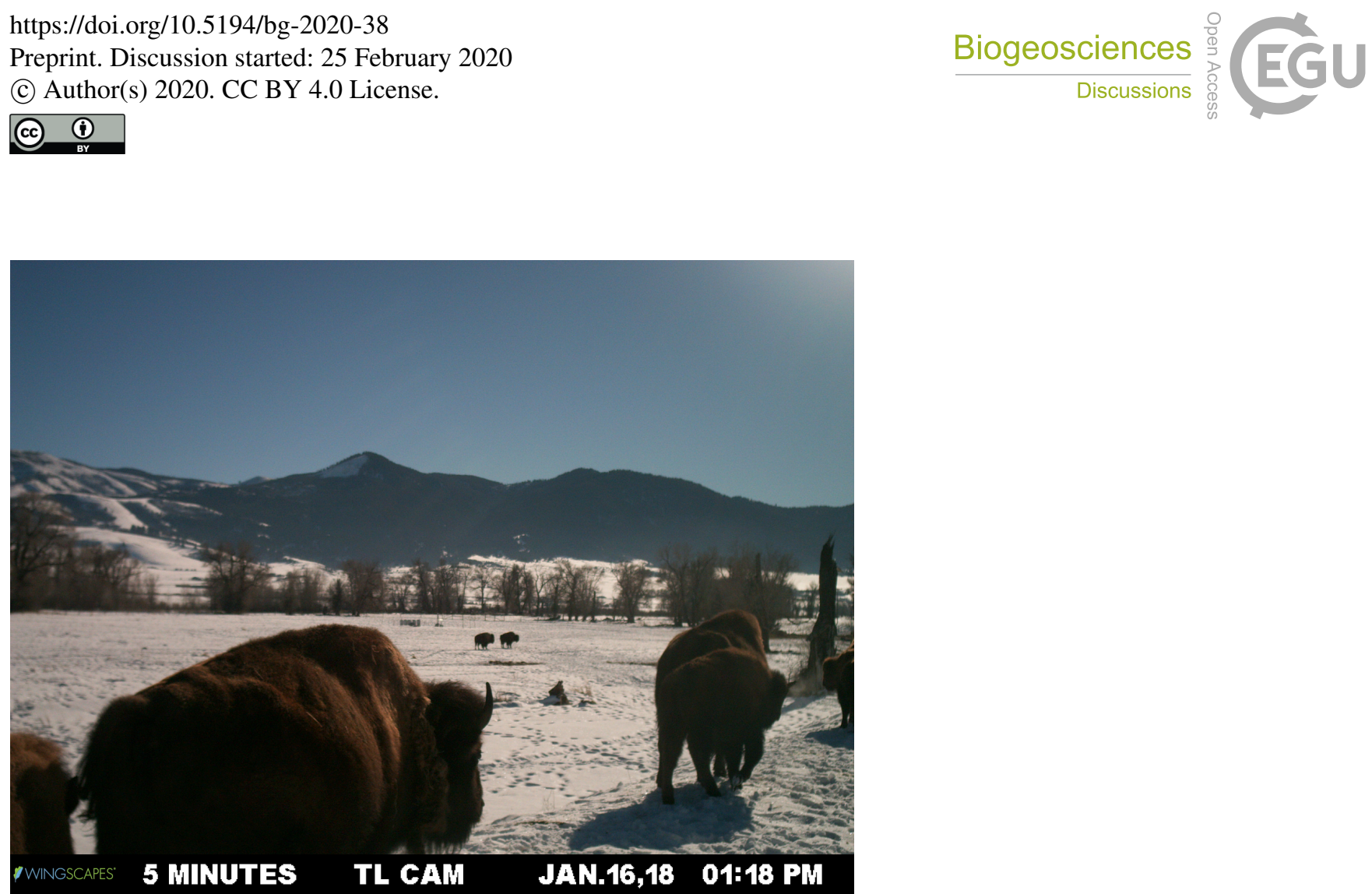

Figure 2: A sample image of bison as viewed from the south-facing time-lapse camera located to the north of the study area (Figure 1). The eddy covariance installation is visible toward the center of the study site. 


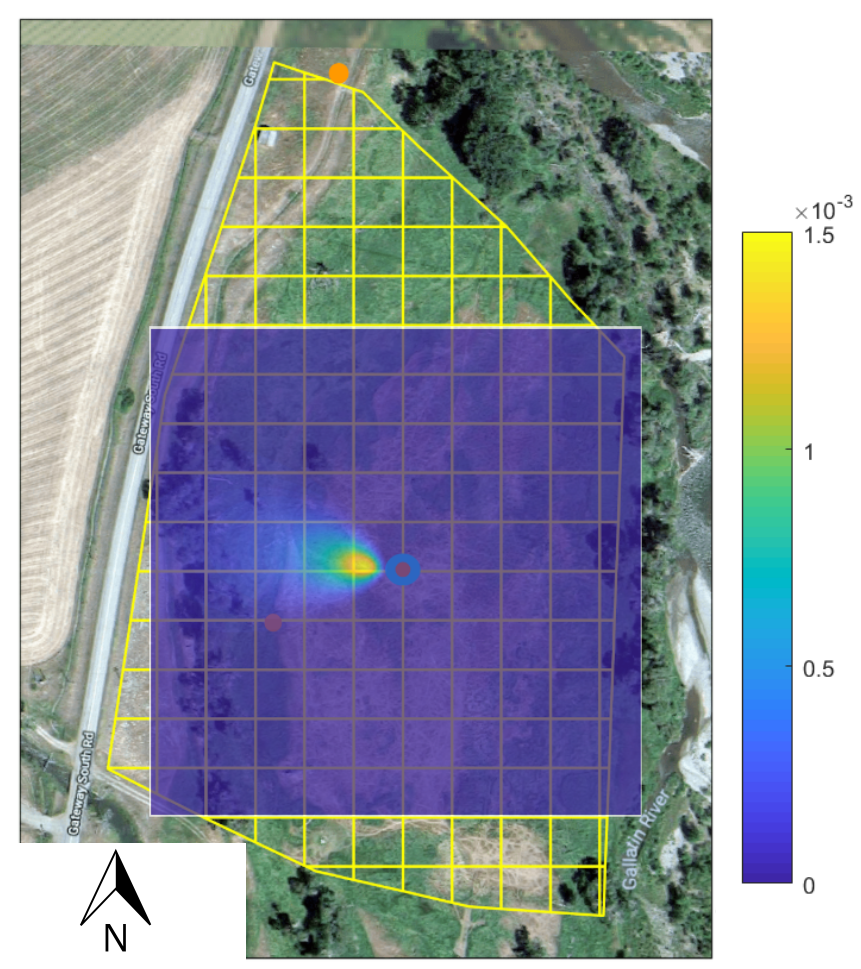

Figure 3: An eddy covariance flux footprint calculated following Hsieh et al. (2000) and Detto and Katul (2006) at $1 \mathrm{~m}$ resolution for a single 30-minute interval is shown superimposed on an aerial photograph of the study pasture with a 20-meter grid overlaid (Fig. 1). The fraction of the footprint in each grid box is shown in the legend is summed for each $49520 \mathrm{~m}$ pixel to calculate the contribution of each pixel to the total flux. Background image: Google, Maxar Technologies and the USDA Farm Service Agency $@ 2018$. 

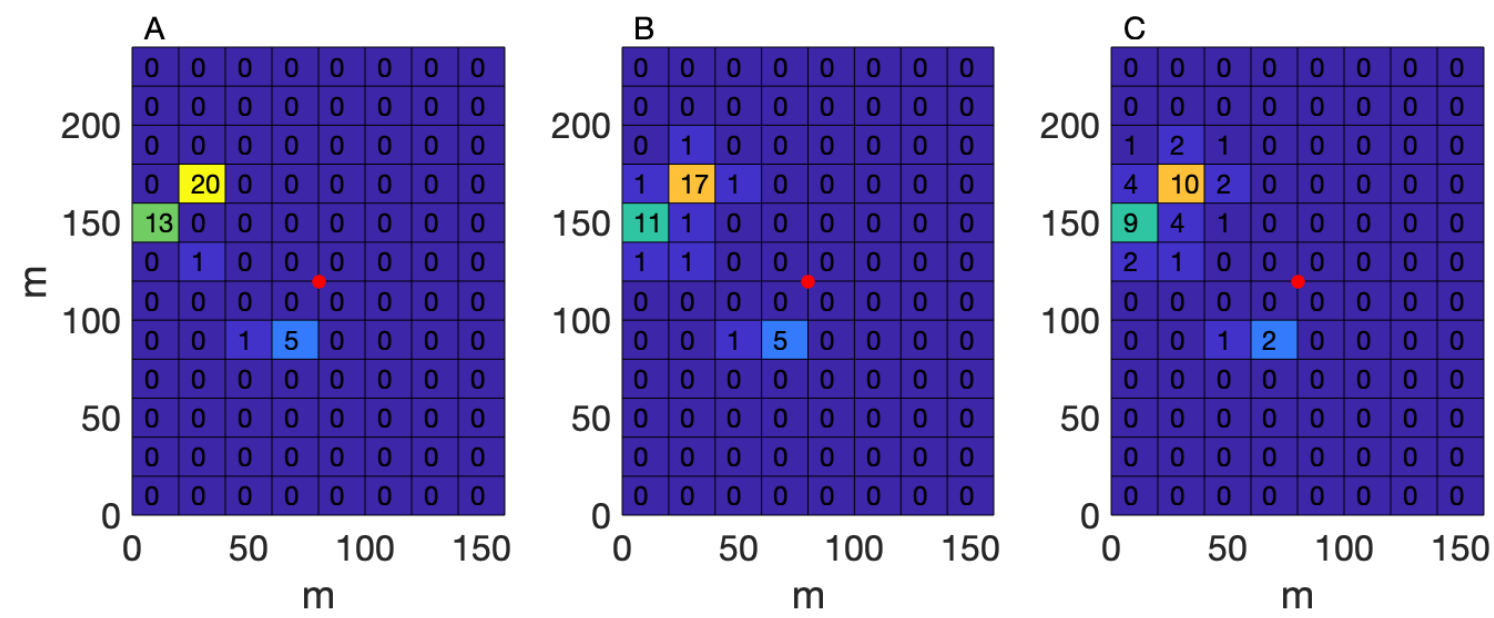

Figure 4: The number of bison observed per grid cell at 16:30 on January 11, 2017 (A) and a distributed bison location map generated using two-dimensional Tikhonov Regularization with a Lagrange multiplier of 0.1 (B) and 0.5 (C). 

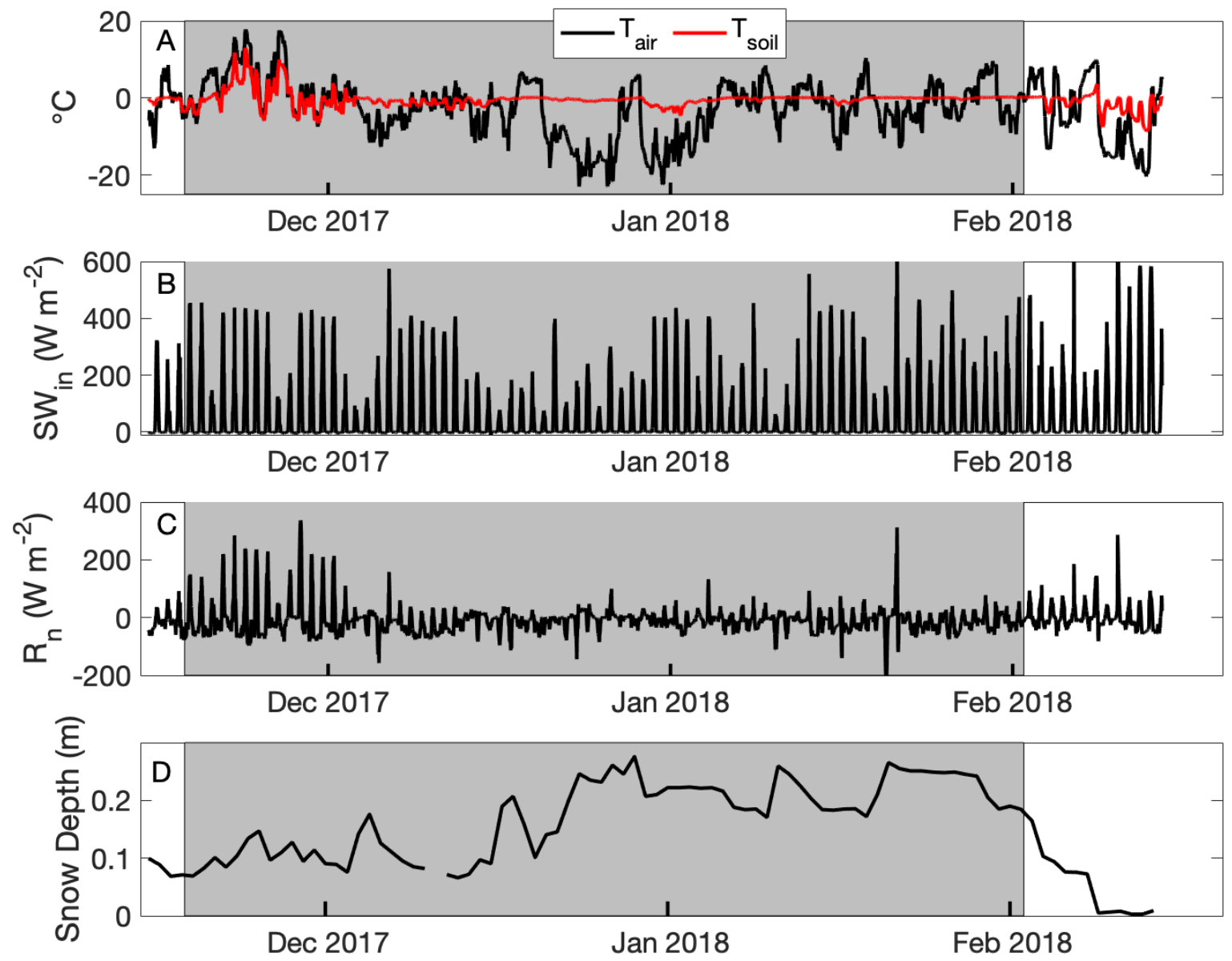

Figure 5: Air temperature $\left(T_{\text {air }}\right)$, soil temperature $\left(T_{\text {soil }}\right)$, incident shortwave radiation $\left(S W_{\text {in }}\right)$, net radiation $\left(R_{n}\right)$, and snow depth from a micrometeorological tower enclosed within an electric fence on a bison pasture near Gallatin Gateway, Montana, USA. Bison were present in the pasture during the interval bounded by the grey background. 


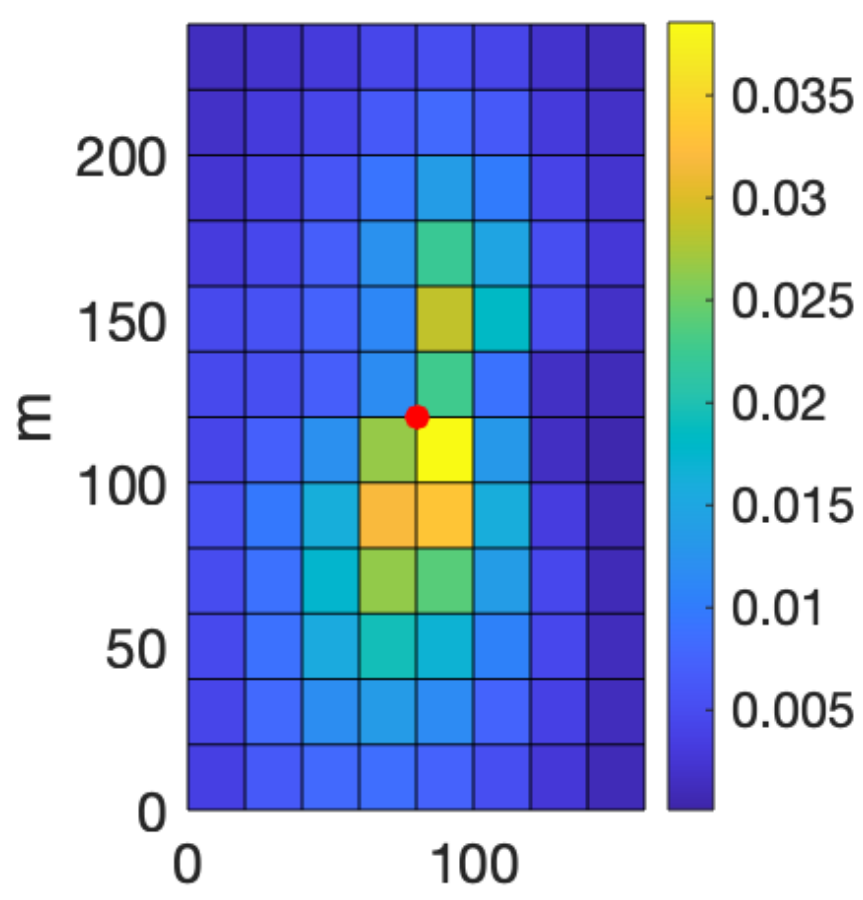

$\mathrm{m}$

505 Figure 6: The pasture area with the daytime (0700-1700) flux footprint averaged over the entire study period for the $20 \mathrm{~m}$ grid demonstrated in Figure 1. The red dot denotes the location of the eddy covariance tower. On average $86 \%$ of the footprint area resided within the dimensions of the field during the measurement period. 


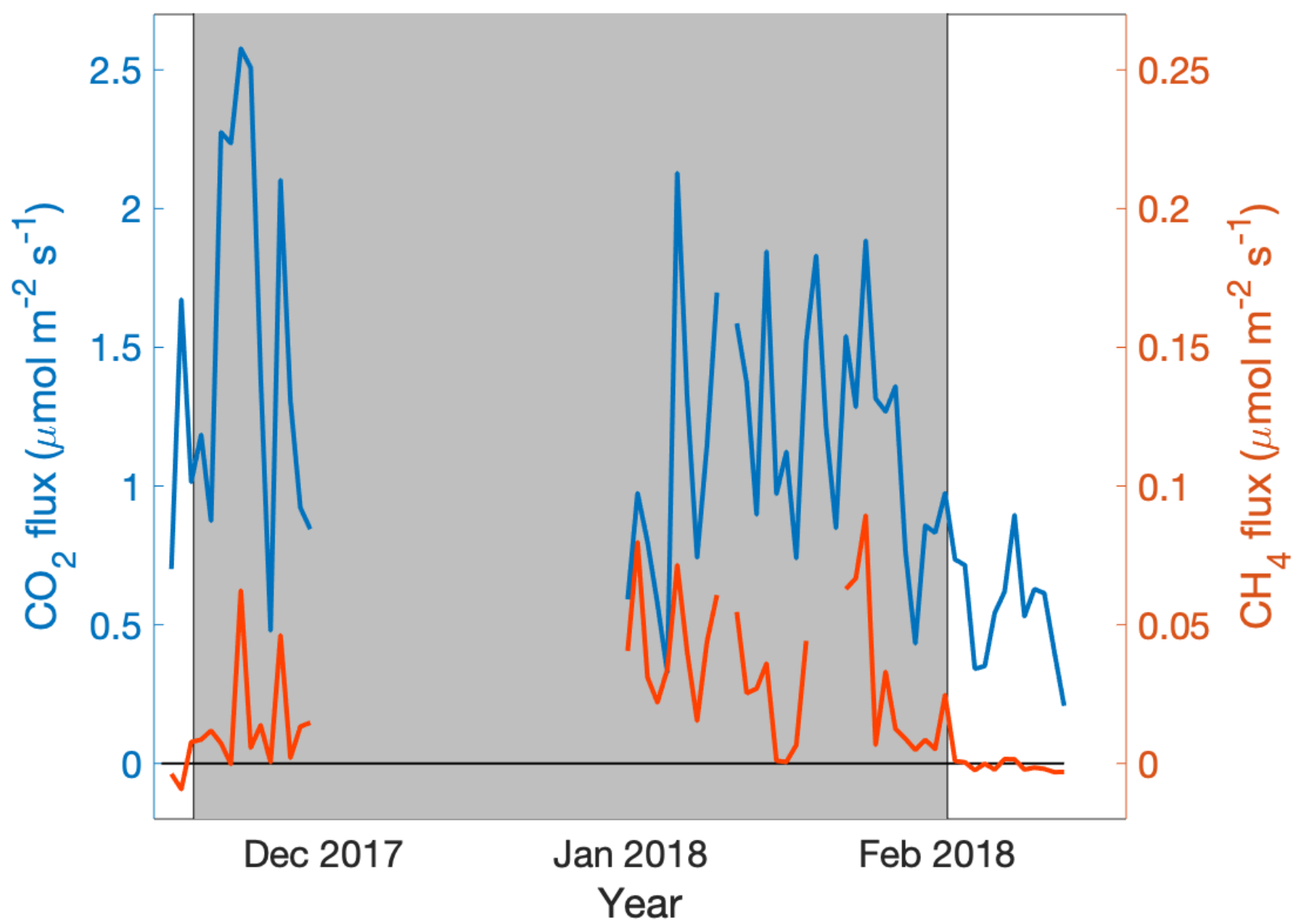

Figure 7: Daily median carbon dioxide and methane fluxes during daytime hours (0700-1700) from a pasture near Gallatin Gateway, MT, USA. The gray background denotes the interval during which bison were present. 


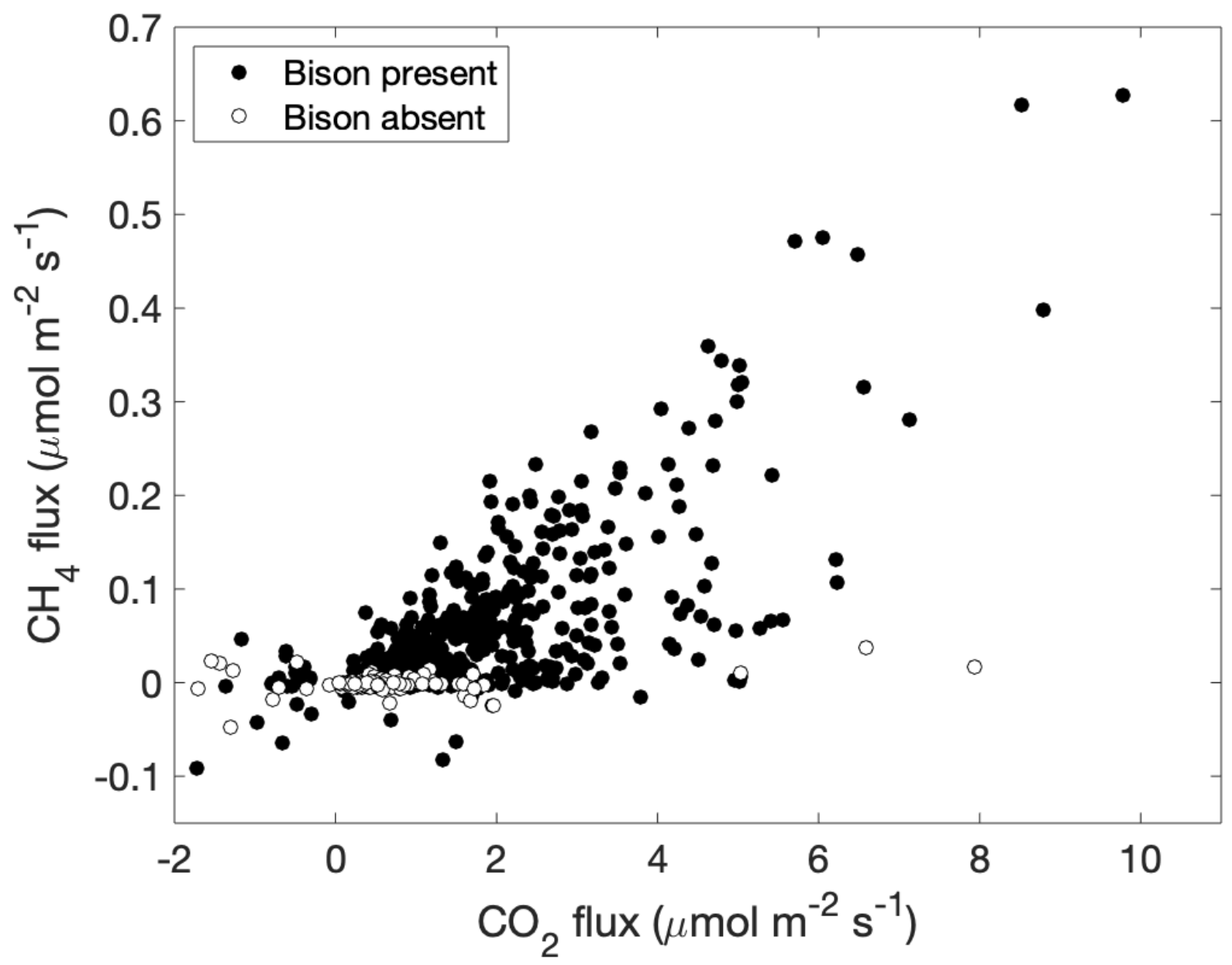

Figure 8: The relationship between carbon dioxide and methane fluxes from the study pasture is shown for periods when bison were present (filled circles) and when bison were absent (open circles). 

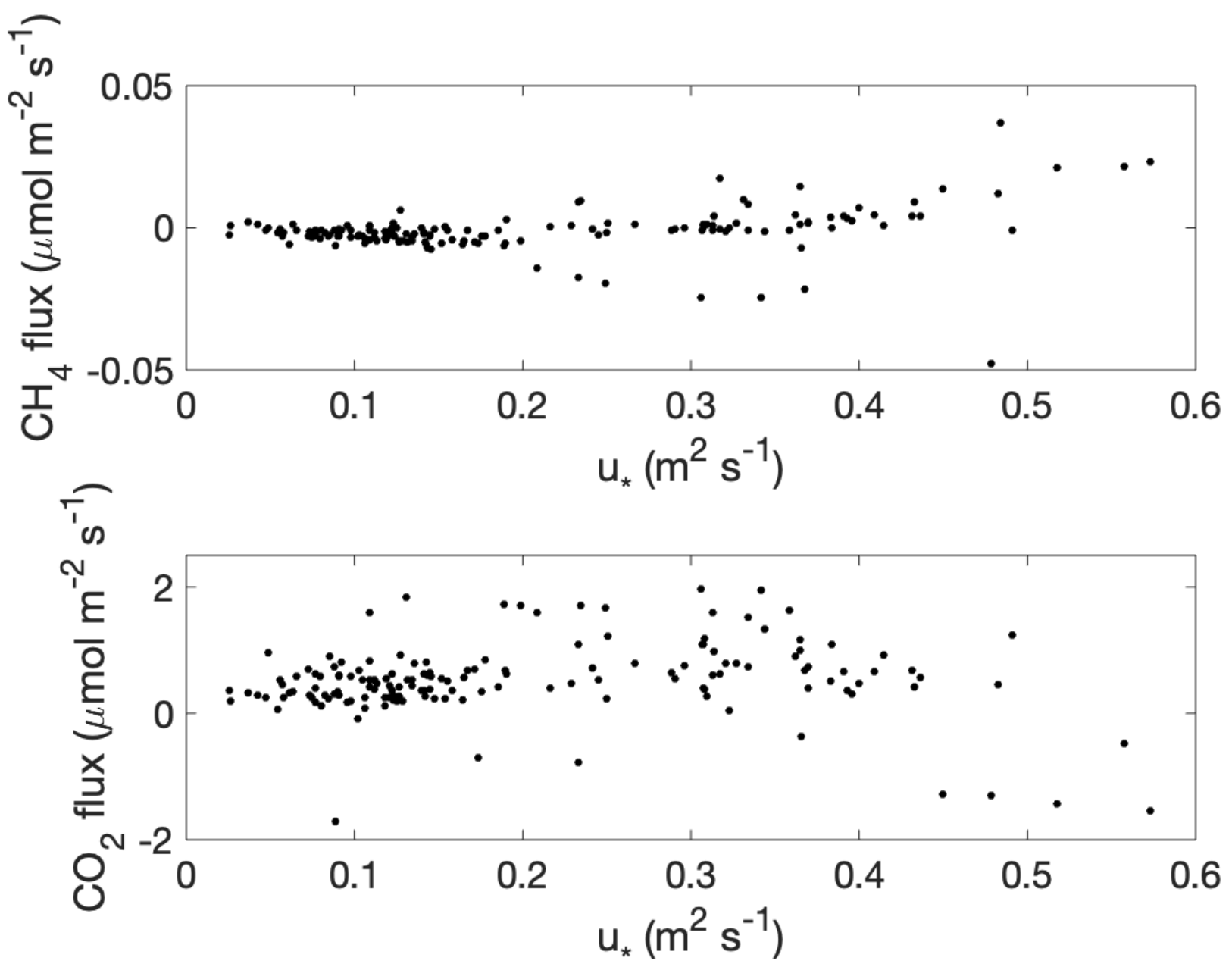

515 Figure 9: Methane (A) and carbon dioxide (B) fluxes as a function of friction velocity $(u *)$ when bison were absent from the study pasture. 

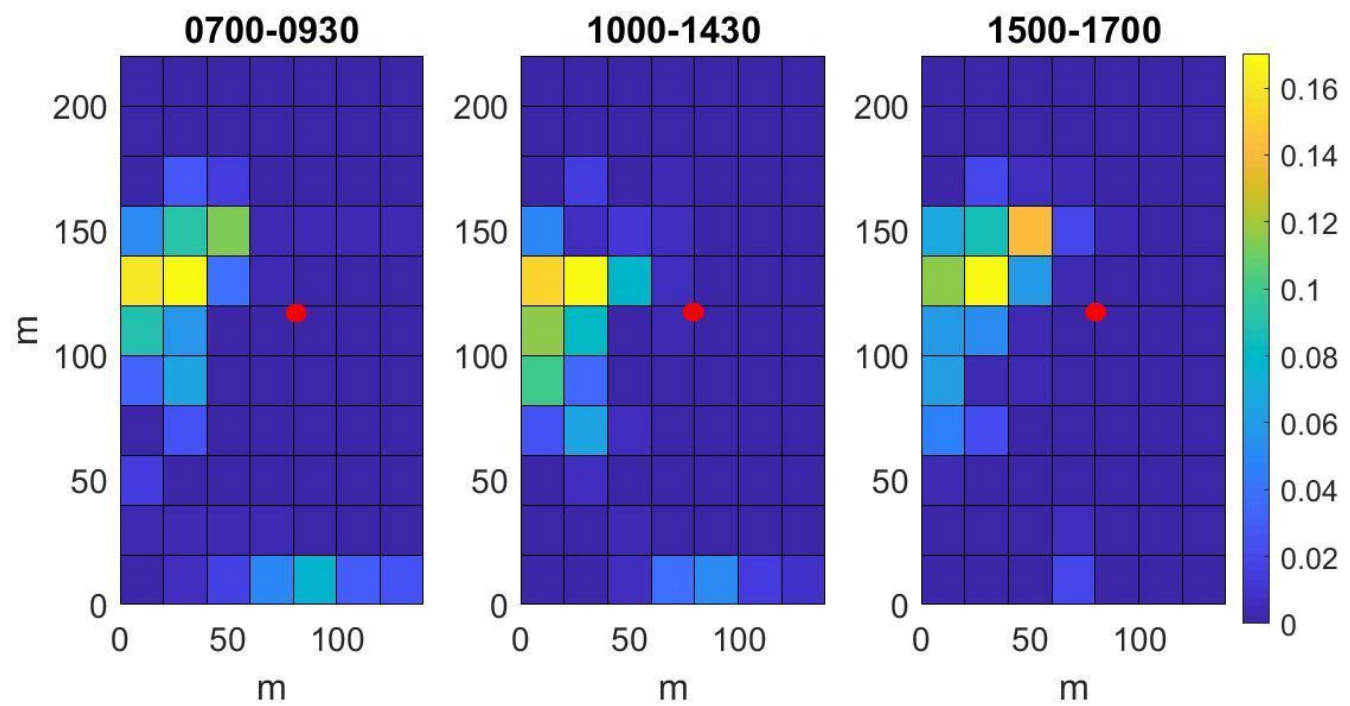

Figure 10: Average proportional bison density for three periods of the day. Each colored pixel represents a 20-meter grid square, red dots denote the location of the eddy covariance tower, and subplot titles refer to local time. Color denotes average proportion of bison present in each grid cell for the 40-animal herd. 


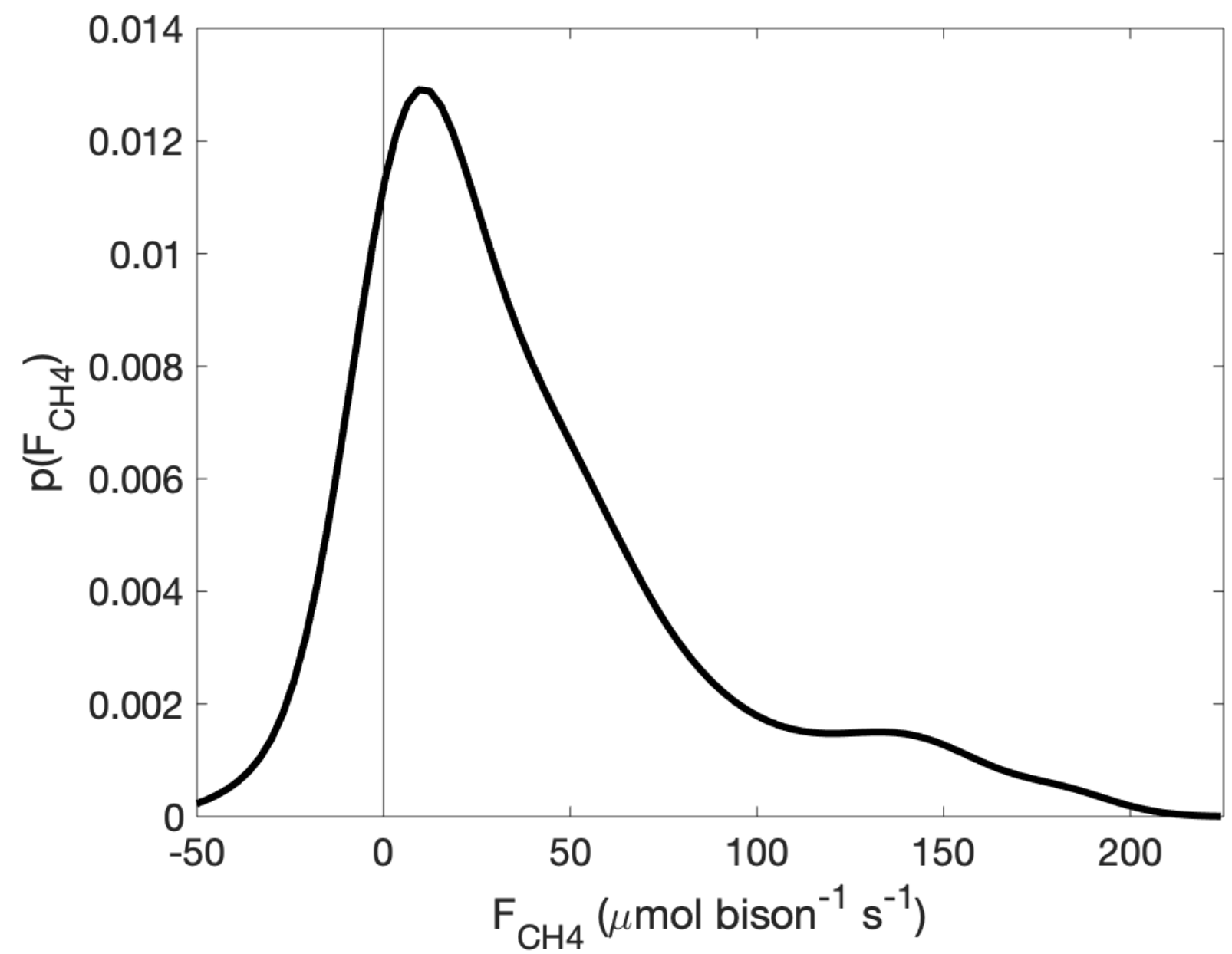

Figure 11: The distribution ( $\left.\left(\mathrm{F}_{\mathrm{CH} 4}\right)\right)$ of methane efflux $\left(\mathrm{F}_{\mathrm{CH}}\right)$ on a per-bison basis approximated using a kernel density estimate. 
https://doi.org/10.5194/bg-2020-38

Preprint. Discussion started: 25 February 2020

(c) Author(s) 2020. CC BY 4.0 License.
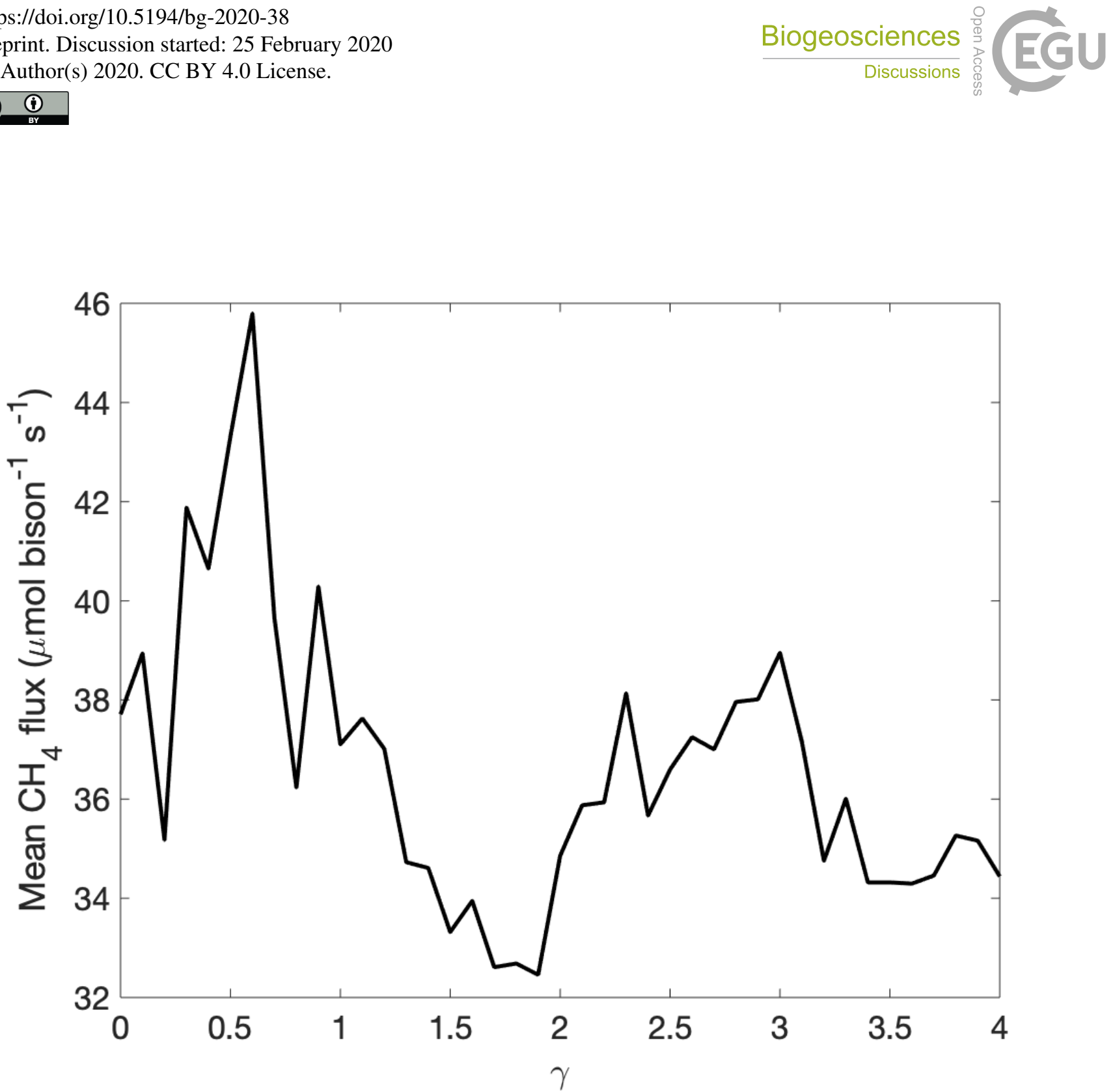

Figure 12: Mean methane efflux on a per-bison basis as a function of spatial smoothing of bison location estimates using the two-dimensional Tikhonov Regularization approach described in Stoy and Quaife (2015) for different values of the Lagrange multiplier $\gamma$. 
https://doi.org/10.5194/bg-2020-38

Preprint. Discussion started: 25 February 2020

(c) Author(s) 2020. CC BY 4.0 License.
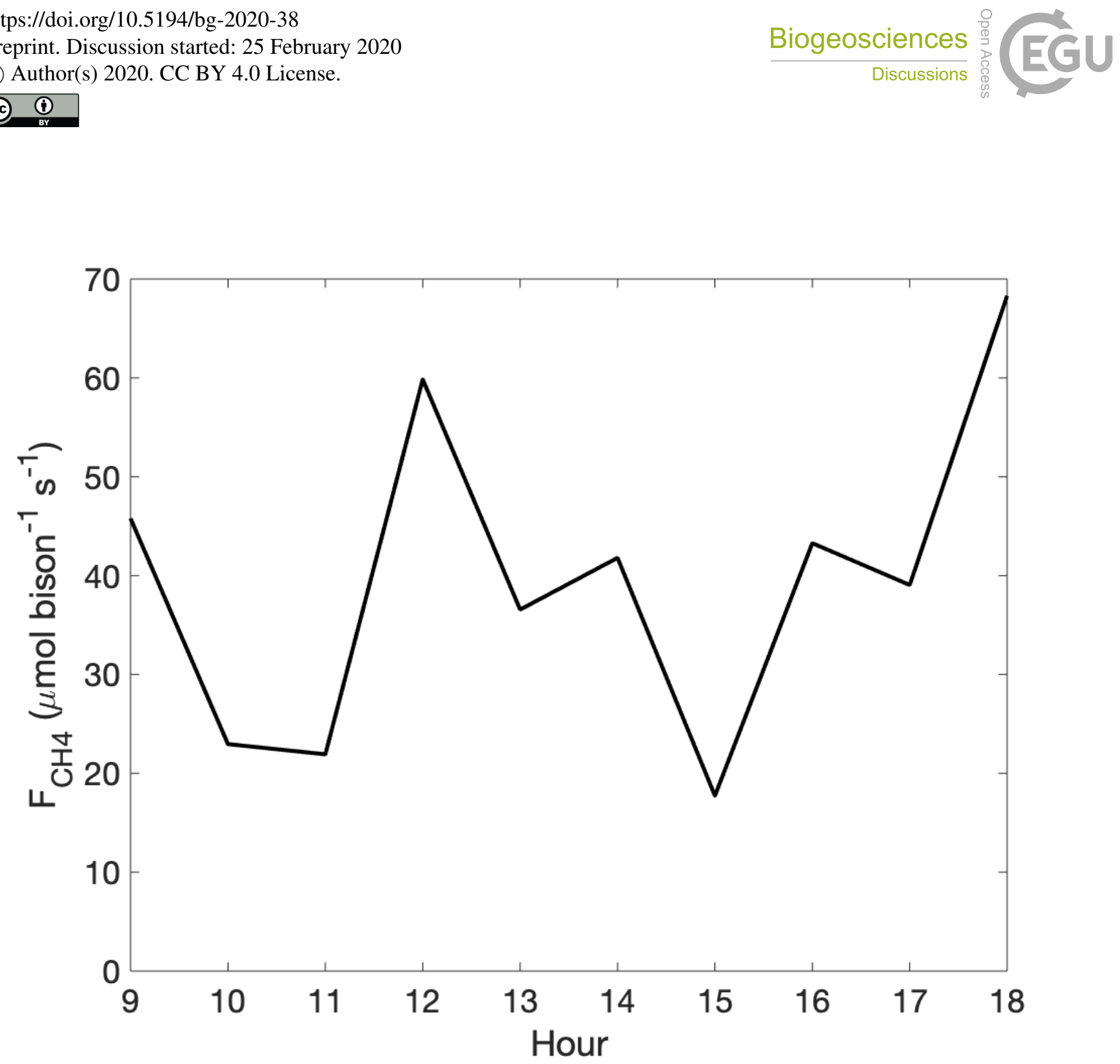

Figure 13: The diurnal pattern of mean per-bison methane flux $\left(\mathrm{F}_{\mathrm{CH} 4}\right)$ across the study period. 